Contents lists available at Journal Redwhitepress
Journal of Educational and Learning Studies
ISSN: 2655-2760 (Print) ISSN: 2655-2779 (Electronic)
Journal homepage: http://journal.redwhitepress.com/index.php/jles

\title{
The development of physical comics handout problem based learning to improve students' creative thinking skills in straight motion students
}

\author{
Enny Zarvianti ${ }^{1}$, Desrianti Sahida ${ }^{2}$ \\ STKIP Muhammadiyah Sungai Penuh
}

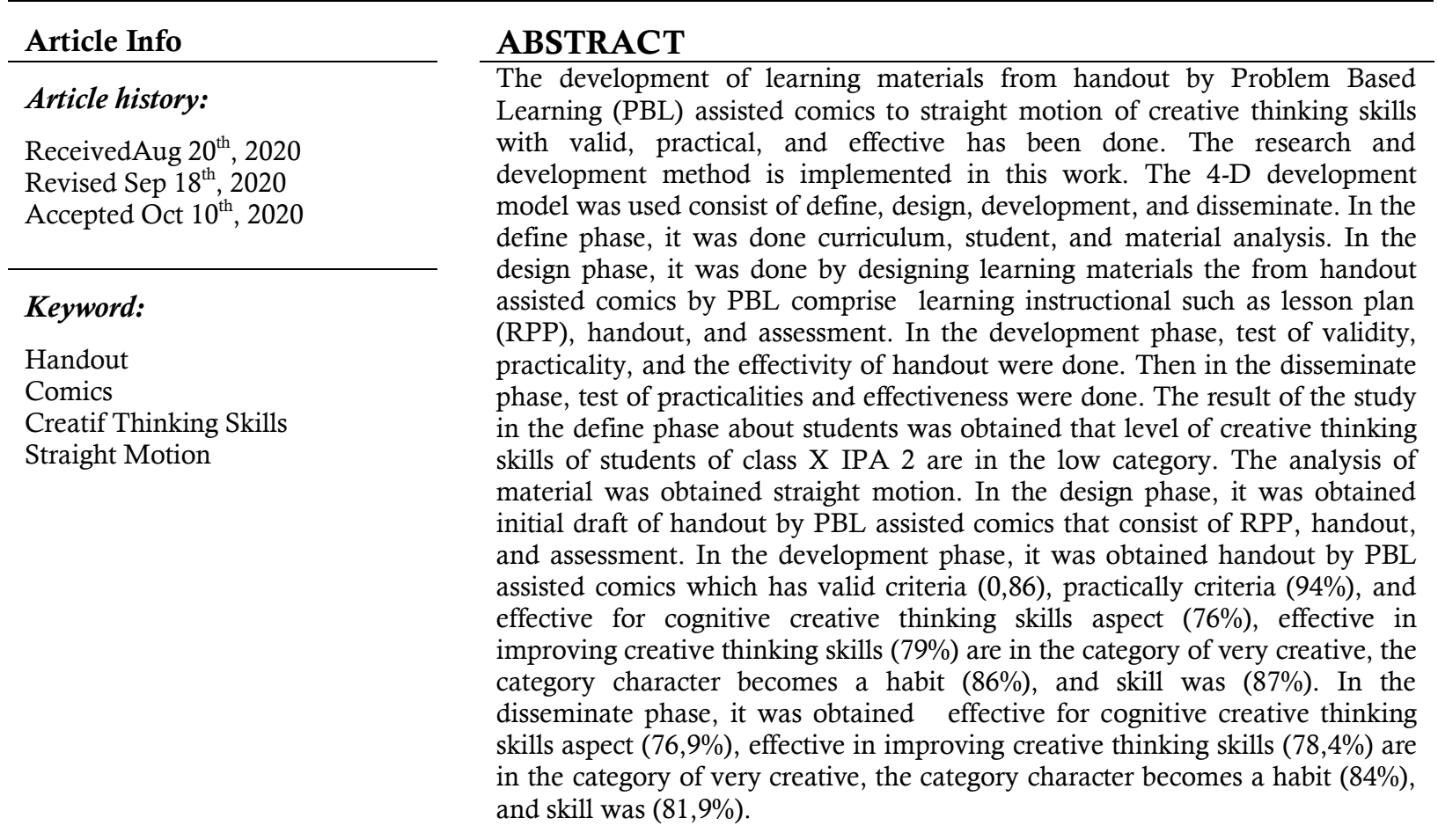

\section{Corresponding Author:}

Enny Zarvianti

STKIP Muhammadiyah Sungai Penuh

Email: ennyzarvianti@gmail.com

\section{Introduction}

Education is a conscious and planned effort to create an atmosphere of learning and the learning process so that students actively develop their potential to have religious spiritual strength, self-control, personality, intelligence, noble character and skills needed by themselves, society, the nation and the state. (National Education System Law No. 20 of 2003). One of the conscious efforts made by teachers in the implementation of education is to develop teaching materials.Panen (2001) and (Andi, 2011) are in line with his opinion about teaching materials, according to him, teaching materials are materials or subject matter that are systematically arranged, which are used by teachers and students in the learning process. 
According to the Directorate of Senior High School Development (2008), the definition of teaching materials is any form of material used to assist teachers in carrying out teaching and learning activities. The material in question can be in the form of written material or unwritten material. Based on these definitions, it can be concluded that teaching materials are a learning component used by teachers as learning materials for students and assisting teachers in carrying out teaching and learning activities in the classroom. Types of Teaching Materials Types of teaching materials are divided into several grouping criteria. According to Koesnandar (2008), There are two types of teaching materials based on the subject, namely: (a) teaching materials designed for learning, such as books, handouts, worksheets and modules; (b) teaching materials that are not designed but can be used for learning, for example clippings, newspapers, films, advertisements or news. Koesnandar also stated that when viewed from its function, the teaching materials designed consist of three groups, namely presentation materials, reference materials, and independent study materials. Thus in its development, handouts must meet the elements stipulated in the handout-making regulations prepared by the government. (b) teaching materials which are not designed but can be used for learning, for example clippings, newspapers, films, advertisements or news. Koesnandar also stated that when viewed from its function, the teaching materials designed consist of three groups, namely presentation materials, reference materials, and independent study materials. Thus in its development, handouts must meet the elements stipulated in the handout-making regulations prepared by the government. (b) teaching materials which are not designed but can be used for learning, for example clippings, newspapers, films, advertisements or news. Koesnandar also stated that when viewed from its function, the teaching materials designed consist of three groups, namely presentation materials, reference materials, and independent study materials. Thus in its development, handouts must meet the elements stipulated in the handout-making regulations prepared by the government.

Various forms of efforts have been made by the government, one of the efforts made is to change the KTSP curriculum to the 2013 curriculum, where the 2013 curriculum rests on the form and learning activities in the classroom (Festiyed, 2015). The 2013 curriculum also emphasizes the modern pedagogical dimension in learning, namely using the scientific approach (scientific appoach) (Kemendikbud, 2014). The scientific approach to learning as intended includes the 5 step (observing, asking, gathering information, associating, and discussing), thus it should be able to bring up all competencies. The learning process touches three domains, namely attitude competence, knowledge competence, and skills competency (Kemendikbud, 2013).

The ability to think creatively is one part of knowledge competence, in the form of an individual's life skills that are needed to overcome life problems in this information age. Through science education students can recognize, respond to and appreciate science and technology, and instill habits of critical, creative and independent thinking and scientific behavior (Ekoningtiyas, 2013). According toMunandar (2009) Students' creative thinking abilities are based on indicators of the four components of creative thinking abilities, namely fluency, flexibility, originality, and elaboration.The level or score of students' creative thinking abilities can be measured. According to Gregor (2007), measuring students' creative thinking skills can also be done based on what students communicate, verbally or in writing. So it can be concluded that the ability to think creatively is a person's ability to produce something new, both in the form of ideas and real work that is different from the existing ones that can be observed. during the learning process.

Learning physics at MAN Sebukar has been going well. However, the acquisition of student competencies has not fully reached the Minimum Completeness Criteria $(\geq 70)$. This is due to the low ability of students to think creatively. Based on the results of the analysis of students, it can be seen that the creative thinking skills of class X IPA 2 MAN Sebukar students are in the low category. This can be seen from the scores achieved by students of class X IPA 2 MAN Sebukar on each indicator of creative thinking ability on average smaller than $60 \%$ as in Figure 1 .

Figure 1 shows the scores of students' creative thinking abilities are in the low category. According to Siswono (2005), increasing the ability to think creatively means increasing the ability scorelearners in understanding problems, fluency, flexibility and novelty of problem solving. In order for the intended improvement to occur in the learning process, creative and innovative teachers are needed in planning learning, both in selecting learning models and in selecting teaching materials.

PBL learning model is a series of activities in the learning process oriented towards solving problems faced scientifically. PBL is a learning model that uses real-world problems as a context for students to learn about problem solving skills, as well as to acquire essential knowledge and concepts from 
subject matter (Barell, 2007). According to Abidin (2014) PBL steps are: (a) finding problems, (b) finding work structures, (c) determining problems, (d) collecting and sharing information, (e) finding solutions, (f) determining the best solutions, and (g) present a solution.

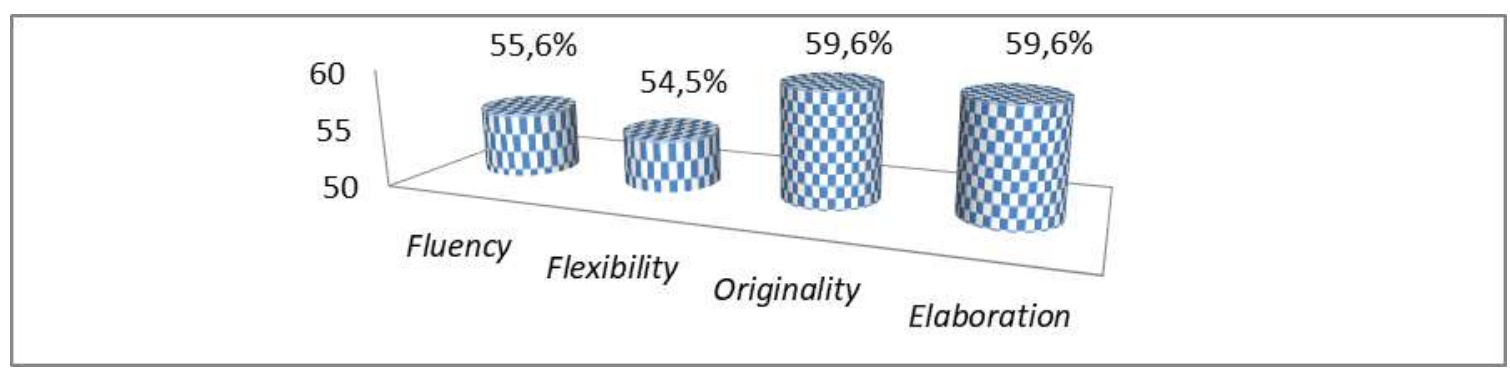

Figure 1. Percentage of indicators for creative thinking abilities of students

One type of teaching material is handout. According to Majid (2006), handouts are sheets containing tasks that must be done by students. That is, student worksheets are something that are deliberately designed to contain tasks that must be done by students. Handout as teaching material that becomes student reading material during the learning process, so it should be presented in an attractive form. Comic assisted handouts are a very good tool to use in the learning process aimed at communicating subject matter.

Straight motion is one of the SMA / MA physics materials in the 2013 curriculum. The purpose of this material is for students to analyze the laws related to straight motion at constant velocity and acceleration and relate them to problems in real life. In addition, in this material students are also required to be able to carry out simple experiments.

Based on the description above, it needs to be developed handout bcomic-assisted PBL to improve students' creative thinking skills in straight motion material. With the aim of producing teaching materialsvalid, practical, and effective.

\section{Methods}

This research produces a product in the form of a straight motion handout that is valid, practical, and effective. Based on the statement of the problem that has been stated, the research conducted is research and development. According to Sugiyono (2008) research and development methods are research methods used to produce certain products.Comic-assisted PBL-based handout development this using a model Four-D (4-D), proposed by Thiagrajan (1974).The 4-D development model consists of 4 stages, define, design, develop, and disseminate. The trial of the device was carried out at MAN Sebukar, the test subjects in this study were students of class X IPA 2 MAN Sebukar in the 2016/2017 academic year, on straight motion material with constant velocity and acceleration. The number of students in class X IPA 2 MAN Sebukar is 21 people.

The data collected in this study are; 1) data validity is obtained from the results of product validation developed in the form of handout comic-assisted PBL by validators who are experts in their fields; 2) practical data obtained from the results of limited trials in the field regarding the practicality of the product being developed; 3) the effectiveness data is obtained based on the results of limited trials in the field regarding the learning outcomes of students after using the product, the results of observations of attitudes, and the results of observations of students' skills. The data analysis technique used is descriptive analysis which describes the validity. The validity analysis used the Aiken's V formula (Azwar, 2015) to analyze it, the descriptive analysis proposed by Arikunto (2010)

\section{Results and Discussion}

Determination of handout needs is carried out through analysis including: preliminary analysis (curriculum analysis), student analysis, and material analysis. Through this analysis, the handout needs were formulated. The results of the analysis will form the basis for developing the handout. The results at 
this planning stage are in accordance with the expectations that the objectives at the planning stage can be achieved properly. The device development carried out has been based on the results of this first stage.

In curriculum analysis, an assessment of the curriculum used by MAN Sebukar was conducted. The curriculum used by MAN Sebukar is the 2013 curriculum. According to the needs of this study, researchers will use class $\mathrm{X}$ as the subject of this study by implementing the 2013 curriculum.

Student analysis is carried out to determine the achievement of student competencies and the problems faced by students in learning. Problem analysis is a process characterized by data collection to see the problems and potentials that can be developed (Brown, 2002). The results of the analysis of students showed that rThe end result is the acquisition of student competencies due to the low ability of students to think creatively. Based on the results of the analysis, it was found that students of class X IPA 2 MAN Sebukar have the ability to think creatively with a low category. So that we need teaching materials that can improve the ability to think creatively in order to foster an understanding of straight motion material with constant velocity and acceleration.

At the material analysis stage, an assessment and adjustment is made between the curriculum requirements. Where in the learning process students are required to be able to find their own concepts and principles from some of the observed and investigated phenomena. Based on the results of the material analysis, learning is prepared that supports the achievement of competencies, according to the needs of students, and the material to be taught. The PBL model is a form of learning model that regulates teaching in such a way that students are not presented with lessons in their final form, but it is hoped that students will organize the lessons themselves (Kemendikbud, 2013). In the PBL model, learning is carried out by students based on the teacher's instructions in understanding a problem.

Handout design is carried out based on the analysis that has been done previously. Handouts are developed based on needs that have been formulated at the definition stage. Each analysis result has contributed to the development of a handout consisting of lesson plans, handouts, and assessments.

The first step in designing a handout is compiling a test referring to the criteria for the formulation of assessment indicators for the handout. These indicators are formulated based on the criteria to be measured. Furthermore, all components of the handout developed were assessed in terms of validity, practicality, and effectiveness.

The second step is media selection. In developing this handout, the media selection is based on the results of material analysis and adjusted to the needs of students. It is intended that students can more easily find the concept of the material being studied in carrying out learning activities because what they learn is what is really around them.

The next step is format selection. Handout design is carried out in accordance with the format used in the reference. In this case the format is focused on improving the creative thinking skills of students who are developed in learning activities. Handouts are developed in comic form. In its use as a teaching material, handouts need to be accompanied by other teaching materials.

The learning steps developed in the lesson plan, handout, and assessment refer to the PBL model with a scientific approach to improve students' creative thinking skills. It aims to assist students in achieving their goals in accordance with the objectives set in the analysis of learning objectives. To measure students 'achievement of learning objectives, an assessment tool is needed that can measure students' achievement of learning competencies.

The design of the assessment refers to Permendiknas No. 20 of 2007 concerning education assessment standards. The assessment tools developed concern the aspects of knowledge, attitudes, and skills of students, in accordance with the learning objectives that have been developed from basic competencies. Cognitive assessment using description tests. Attitude assessment and skills assessment using a questionnaire sheet of respondents as observers during the learning process.

\section{Validity test}

Based on the research results that have been described, it is found that the handout developed is in the valid category. The data from the validation calculation on average have not reached number 1 . This shows that in the development of handouts, lesson plans, and assessments there are still deficiencies. But even so, the product that the author has developed has advantages. The strength that can be felt is that in its product development, it has paid attention to the relationship between the components and the suitability of the handout, lesson plan and the learning model used. The learning model used is the PBL 
model to improve students' creative thinking skills. Another advantage is that in one of PBL's steps in the handout, comics are presented.Science comics are suitable for use as an alternative learning media and learning resources in order to solve problems in science learning (Sudjana, 2005). In terms of language, the product developed uses good and correct Indonesian and uses the right EYD (Guidelines for the Development of Teaching Materials, 2008).

\section{Practicality Test}

Practicality test was conducted to determine the practicality level of the handout. The results of the RPP implementation test are in the practical category. In general, the learning activities described in the lesson plans have been carried out in the learning process. It means that the learning steps developed in the device can be implemented in the learning process.

Through the teacher response test, information was obtained about the practicality of the comic handouts that were developed. The results of the RPP implementation test are in the practical category with a value of $97 \%$. This means that a straight motion RPP with constant speed and acceleration is practically used to plan the learning process. The handout practicality test results are in the practical category with a value of $93 \%$. The handout developed is practically used as a teaching material in the learning process. The result of the practicality test is in the practical category with a value of $91 \%$. Practical assessment developed for use in the learning process.

The student response test was carried out to determine the level of practicality of the handouts developed. Student response tests are carried out when students have used all the teaching materials developed in the learning process. The handout practicality test results were in the practical category with a value of $87.4 \%$ for the first meeting, $91.2 \%$ for the second meeting, the third meeting with a value of $92.4 \%$, and the fourth meeting with a value of $93.6 \%$. This means that handouts in the form of physics comics on straight motion material with constant velocity and acceleration are practically used as a learning resource. In general, the handouts developed are easy to use and very helpful for teachers in the preparation, implementation and assessment of the learning process.

\section{Effectiveness Test}

The criteria for effective teaching materials are if after using teaching materials there is a positive impact on teachers and students in the learning process. According to Sukmadinata (2005)learning outcomes on knowledge competencies can be said to be effective if they reach the predetermined KKM (The Minimum Achievement Criteria). The handout developed is said to be effective if students have reached $70 \%$ of the learning objectives that have been created, as the KKM has been set by the education unit and a class has reached classical completeness if $70 \%$ of the students have reached the KKM.

In the assessment of students' knowledge, $79 \%$ of the total number of students had mastered more than $70 \%$ of the learning objectives that had been set with an average value of 76 . This indicated the success of students in finding problems and solving physics problems in the comics contained in the handout. In addition, the PBL step has also succeeded in guiding students in mastering the material by involving students fully in the learning process.

On appraisal attitudes of students $86 \%$ of the total number of students had met $86 \%$ of the attitude assessment indicators set with an average value of 86 , indicating that the attitudes of students were in the very good category and became a habit. In respondents 'observations, as far as the learning process, there are indicators of students' curiosity that are lower than other indicators of attitude, this is because the high curiosity of students cannot be seen clearly by the respondent. This is proved by the frequency of students asking their classmates, and reading the material in handouts and other teaching materials, but not directly asking the teacher or respondent. In response to this problem, The author suggests the teacher to convey to students that there are several indicators of attitudes that must be highlighted by students. So that there was an increase in indicators of curiosity at each meeting.

In the skills assessment $87 \%$ of the total number of students had met the aspects of the skill assessment set with an average score of 87 in the very good category. At the first meeting, the students' skills assessment only reached 80 in the good category, but at the second, third, and fourth meetings it increased so that it reached the very good category. However, in the learning process the respondents observed were the low scores of each tool-building skill indicator compared to other skill indicators. This is due to the fact that some members of the group are given the responsibility to arrange the tools, so that the skills of arranging tools for other group members are not seen and observed by the respondents. In response to this problem, The author also suggests the teacher to be conveyed to students, that in the practicum there must be a proper division of tasks and according to the portion for each student. On the 
application of these suggestions, there was an increase in the learning outcomes of skills competencies on the indicators of assembling the tools of students in each meeting.

Based on the results of the assessment of knowledge, attitudes, and skills, the effectiveness of the product being developed can be measured. Based on the effectiveness test carried out, it can be said that the comic-assisted PBL-based handouts that have been developed are in the effective category. In other words, comic-assisted PBL-based handouts can be used in learning so that there is an increase in student learning outcomes.

This is because the use of handouts in learning based on the PBL model is felt by students to increase enthusiasm and enjoyment in learning physics. The enthusiasm and pleasure of students in learning can be seen from several indicators of practicality of handouts according to the responses of teachers and students. Indirectly, the enthusiasm and pleasure of students in the learning process has helped students improve their competence. The potential impact for students is also supported by the existence of the PBL model. Students can solve physics problems by linking events around them in the learning process. This is in line with the opinion of Darwis (2014), which states that the learning competence of students can increase with the PBL model.

Apart from having a potential impact on students, this handout also has a positive impact on teachers. The teacher can overcome the learning difficulties of students in physics material which is dominated by material concepts and principles. Teachers can meet the availability of teaching materials that are attractive and easily understood by students and train students to independently solve physics problems. Interesting teaching materials are presented in comic form. This is in line with Syaichudin (2010) who stated that dith high attractiveness to comic teaching materials students are more motivated to understand material taught by the teacher.

In accordance with the objectives of this deployment stage, it is necessary to test the practicality and effectiveness if it is tested in different classes. The practicality test results at the deployment stage are also in the practical category. This is evidenced by the implementation of the lesson plans and the responses of students. The learning steps developed in the lesson plan have been implemented with a score of $97.7 \%$. The teacher's response to the implementation of the lesson plan reached a score of $98 \%$ in the practical category, for handouts it reached a score of $94 \%$ in the practical category, and for the assessment in the practical category with a score of up to $92 \%$. The response of students is also in the practical category with the practicality of handouts reaching $96.6 \%$. Based on these results, it can be stated that the handouts developed were practically used in different classes. From the results of the analysis of the handout effectiveness test at the dissemination stage. In the assessment of students' knowledge, the average score reached 76.9. With a percentage of completeness reaching $78.4 \%$. This shows the success of students in the distribution class in finding problems and solving physics problems in the comics contained in the handouts. In addition, the PBL step has also succeeded in guiding students in the distribution class in mastering the material by involving students fully in the learning process.

In the competency, the attitudes of students reached an average value of $84 \%$ and showed that the attitudes of students were in the very good category overall. However, when viewed from the results of the respondents' observations, the indicators of cooperation, conscientiousness, and responsibility are higher than the indicators of curiosity and communication. This is because the two attitudes are not clearly visible to the respondents, it can be proven by the curiosity of students by communicating directly with group members and collecting and sharing information from other teaching materials. So the writer suggests the teacher to remind students that there are attitude indicators that must be owned and highlighted.

The skill competency reaches an average score of $81.9 \%$ in the very good category. However, there were discrepancies in the results of the achievement of the skill set tool skills indicator at the first meeting, this was based on the responsibility given to some students to assemble the tools so that the other group members did not observe their tooling skills. On this basis, the authors suggest the teacher to remind students to distribute assignments equally, and carry out assignments according to their respective portions. So that for the next meeting there was an increase in the skills indicators of arranging the tools of students. This also happened to the indicators of skills to participate and to write conclusions, with the same treatment,

Based on the results of the assessment of learners' knowledge, attitudes, and skills at the dissemination stage, it can be said that this comic-assisted PBL-based handout is in the effective category, with an average value of $\geq 70$ for each assessment, in the complete and successful criteria. According to 
Riduwan (2008), the results of the average assessment of attitudes, skills, and knowledge can be concluded that the teaching materials developed are in the effective or ineffective category. Based on the effectiveness test that has been implemented, it can be said that the handouts were developed to be effectively used in different classes.

Handout which is developed to improve students' creative thinking skills, the results of increased creative thinking abilities are obtained from the results of the evaluation of the domain of knowledge processed through the gain score equation. Techniques carried out to get the value will be processed through the gain score equationis to do a pre-test at the beginning of the meeting and a post-test at the end of the meeting. Then the first meeting test resultsused to see the increase in creative thinking skills at the second meeting, followed by the test results of the second meeting used to see the increase in creative thinking skills at the third meeting. And to see the increase in creative thinking skills at the fourth meeting used the results of the third meeting. After processing the data through the gain score equation, it can be seen clearly what happened enhancement creative thinking skillscan be seen clearly, where there is an increase in the average score of students, the increase in each meeting.

This is because the use of comic-assisted handouts in learning uses the PBL model, by directly involving students in analyzing and solving problems. The involvement of students in learning provides its own motivation for students to take part in the learning process, this can be seen from several indicators of the practicality of comic-assisted handouts according to the responses of teachers and students. The potential impact for these learners is supported by the existence of the PBL model. Students can solve physics problems in the learning process.

In addition to having an impact on students, this comic-assisted PBL model handout also had a positive impact on teachers. Teachers can overcome students 'learning difficulties in physics material which is dominated by material concepts and principles, teachers can meet the availability of teaching materials that are attractive and easily understood by students, and train students' independence to solve physics problems.

\section{Conclusion}

The results of the development of comic-assisted PBL model-based handouts on straight motion material with constant speed and acceleration based on the PBL model met the criteria of validity, practicality, and effectiveness. The average validity test of comic-assisted handouts was 0.86 with the valid category. The average handout practicality test was $93 \%$ with the very practical category. There was an increase in the competency values of the knowledge, attitudes, and skills of students in each meeting, this shows that the handouts developed were effectively used in learning.

\section{Acknowledgement}

Researchers express sincere gratitude to Kemenristek Dikti which has passed this research for financing. And the researchers also express their thanks to the chairman of the foundation, lecturers, and the entire academic community of STKIP Muhammadiyah Sungai Penuh who has helped researchers in the research process. Furthermore, the entire family of MAN Sebukar as a place for conducting research.

\section{References}

Andi Prastowo. (2011). Metode Penelitian Kualitatif dalam Perspektif Rancangan Penelitian. Jogjakarta: Ar-Ruzz Media.

Arikunto. 2008. Dasar-Dasar Evaluasi Pendidikan. Jakarta : Bumi Aksara

Azwar, Saiffuddin. 2015. Reliabilitas dan Validitas. Yogyakarta: Pustaka Pelajar.

Barell. 2007. Handbook Of Cosmetic Science And Technology. Jurnal New York: Informa Healthcare. Vol. 3. (Diakses 14 April 2016)

Brown, A. 2002. Multimedia Projekemampuan berpikir kreatif in the Clasroom. United States of America: Corwin Press, Inc

Darwis, 2014. Peningkatan Kompetensi Fisika Siswa Dengan Menggunakan Model Pbl Berbantuan Media Komputer Pada Pembelajaran Fisika SMA Muhammadiyah 11 Padang Sidempuan. Tesis Pascasarjana: Tidak diterbitkan.

Direktorat Pembinaan Sekolah Menengah Atas. 2006. Pedoman Penyusunan Bahan Ajar. Jakarta : 
Lukmana, Direktorat Pembinaan Sekolah Menengah Atas.

Ekoningtyas, 2013. Pengaruh Pembelajaran TPS Dipadu dengan Pola Pemberdayaan Berpikir Melalui Pertanyaan Terhadap Metakognitif, Berpikir Kreatif, Pemahaman Konsep IPA. Malang : Universitas Negeri Malang

Festiyed. 2015. Studi Pendahuluan Pengimplementasian Kurikulum 2013 dalam Mengintegrasikan Pendekatan Saintifik Melalui Model Inkuiri dan Authentic Assessment dalam Pembelajaran IPA di Kota Padang. Padang : Universitas Negeri Padang.

Gregor. 2007. Developing Thinking Developing Learning. Jurnal Poland : Open University Press. Vol. 3, (Diakses 14 April 2016)

Kemendikbud. 2013. Permendikbud No.81A tentang Implementasi Kurikulum. Jakarta: Kementerian Pendidikan dan Kebudayaan

Kemendikbud. 2014. Konsep dan Implementasi Kurikulum. Jakarta: Kementerian Pendidikan dan Kebudayaan

Koesnandar. (2008). Pengembangan Bahan Ajar Berbasis Web. [Online] tersedia di http://www.teknologipendidikan .net diakses tanggal 5 Januari 2012.

Munandar. 2009. Mengembangkan Bakat Dan Kreativitas Anak Sekolah. Jakarta: Pt Gramedia

Pannen, Paulina, dkk. 2001. Kontruktivisme dalam Pembelajaran. Jakarta: Depdiknas

Riduwan. 2008. Dasar-Dasar Statistika. Bandung: Alfa Beta

Siswono. 2008. Model Pembelajaran Matematika Berbasis pengajuan dan Pemecahan Masalah untuk meningkatkan kemampuan berpikir kreatif. Surabaya: Unesa University Press

Sudjana.2005. Media Pengajaran. Bandung : PT Sinar Baru

Sugiyono. 2008. Metode Penelitian Kuantitatif, Kualitatif, Dan R\&D. Bandung : Alfabeta

Sukmadinata. 2005. Landasan Psikologi Proses Pendidikan. Bandung: PT Rosda Karya

Syaichudin. 2010. Pengembangan media komik pembelajaran matematika untuk meningkatkan pemahaman bentuk soal cerita bab pecahan pada siswa kelas V SDN Ngembung. Journal Teknologi Pendidikan 10 (Diakses 14 April 2016)

Thiagrajan. 1974. Instructional Development For Training Teachers Of Exceptional Children. Indiana : Indiana University Bloomington

Undang-Undang RI Nomor 20 Tahun 2003 Tentang Sistem Pendidikan Nasional. Jakarta: BNSP 